KOŚCIÓŁ I PRAWO 8(21) 2019, nr 2, s. 189-202

DOI: http://dx.doi.org/10.18290/kip.2019.8.2-12

\author{
Jarosław Krzewicki
}

\title{
UWAGI CO DO PRAWNEJ OCHRONY OSÓB STARSZYCH I JEJ WPŁYWU NA KSZTAŁTOWANIE SIE POSTAW MORALNO-SPOŁECZNYCH
}

\begin{abstract}
Starość jest kondycją biologiczną, która implikuje określoną pozycję społeczną [Rudnik 2016, 201-19], generuje szereg działań i postaw. Jej ocena wyrasta m.in. z godności osoby ludzkiej oraz roli i pozycji, jaką przypisuje się osobom starszym $\mathrm{w}$ społeczeństwie. Fundamentalna równość w prawie domaga się zróżnicowanej i skutecznej ochrony poszczególnych grup. Jednym z czynników różnicujących potrzebę ochrony jest właśnie starość, stąd rodzi ona konieczność regulacji prawnych celem zagwarantowania osobom należnych im praw [Zamelski 2016, 334]. Innego rodzaju potrzeby wykazują osoby w wieku podeszłym, a innego w dziecięcym czy dojrzałym.

O starości możemy mówić w sensie ekonomicznym, chronologicznym, biologicznym, psychologicznym i prawnym [Frąckiewicz 2007, 17]. Pierwszy i ostatni sens jest zbieżny, bowiem dotyczy wieku produkcyjnego oraz nabycia pewnych przywilejów określanych przez szereg uprawnień, w tym emerytalnych. Trzy pozostałe warunkowane są indywidualną kondycją osoby oraz wpływającym na nią biegiem czasu. Mają one znaczenie przy prawnym definiowaniu pojęcia starości.

Prawo i moralność wzajemnie się warunkują. W niniejszych rozważaniach zostanie podjęta próba odpowiedzi na pytanie, w jaki sposób prawny
\end{abstract}

KS. DR JAROSŁAW KRZEWICKI - Papieski Uniwersytet Świętego Tomasza z Akwinu; adres do korespondencji: Largo Angelicum 1, 00184 Roma RM, Włochy; e-mail: krzew@libero.it; https://orcid.org/0000-0002-9595-9497 
wymiar starości, czyli obowiązujące normy prawne względem osób starszych, wpływają na kształtowanie się moralnych postaw. Przedmiotem rozważań będzie podstawowa i teoretyczna zależność obu tych faktorów na gruncie stosunków powinnościowych między prawem a moralnością w odniesieniu do osób starszych w społeczeństwie sprowadzona do kilku uwag.

\section{OBSZAR REGULACJI PRAWNEJ}

W odniesieniu do obszaru regulacji prawnej dotyczącego osób dotkniętych starością, to wychodząc z definicji prawnej starości, możemy wskazać na główne obszary, w których ustawodawca przejawia swą aktywność [Kijak i Szarota 2013, 24-30]. I tak są to zagadnienia takie jak: rynek pracy, opieka medyczna, socjalna i pielęgnacyjna, możliwość samodecydowania, dostępność do usług finansowych, problem wykluczenia i integracji, dostęp do kultury, rekreacji i wypoczynku, stosunki rodzinne, prawo budowlane, bezpieczeństwo i problem przemocy, prywatność i ochrona danych, polityka mieszkaniowa, edukacja, transport i inne.

W polityce państwa względem osób starszych najwięcej uwagi poświęca się rynkowi pracy [Urbaniak 2016, 72-88]. Prymat ekonomii nad osobą sprawia, że nie zawsze jest tak, by osoby starsze miały możliwość samorealizacji zgodnie $\mathrm{z}$ indywidualną kondycją psychofizyczną. Możliwość pracy $\mathrm{w}$ odpowiednim zakresie wpływa na ich status materialny, społeczny i psychiczny, chroniąc je przed alienacją, zagubieniem czy szeregiem upokorzeń.

Innym obszarem jest dostępność świadczeń pieniężnych, w tym dostępność kredytów czy ekonomicznych środków wsparcia [Kłobukowska 2016, 72]. Również problem mieszkań i związanych z nimi odpowiednich dostosowań architektonicznych czy urbanistycznych, tak by życie osób starszych mogło przebiegać $\mathrm{w}$ naturalnym środowisku w odpowiednich sprzyjających warunkach, bez konieczności lokowania ich w przystosowanych do tego specjalistycznych ośrodkach, często niewydolnych i nie najlepiej funkcjonujących. Ich jakość oraz standard jest innym obszarem, jakim zajmuje się prawo, gwarantujące seniorom określony zakres pielęgnacji i opieki, czasem niestety, mimo istniejących przepisów, wciąż pozostawiający wiele do życzenia. 
Ustawodawca zachowuje istotny wpływ na stosunki rodzinne, zwłaszcza gdy chodzi o sprawę odpowiedzialności cywilnej czy karnej. W pierwszym przypadku chodzi np. o zobowiązania alimentacyjne, w drugim o zabezpieczenie oraz rozliczenie naruszeń praw, takich jak przemoc fizyczna czy psychiczna i inne. Ryzyko wykluczenia społecznego najczęściej zachodzi w rodzinie i we własnym środowisku. Problem przemocy względem osób starszych jest szczególnie delikatny, bowiem dotyczy osób, które często dotknięte są pewnym stopniem upośledzenia i niepełnosprawności, a zatem nie potrafią się bronić, a krzywda im wyrządzona zwielokrotnia się ze względu na ich stan psychiczny i fizyczny [Górnicka 2018]. Ponadto ważny jest dostęp do edukacji [Pikuła 2014, 130], uczestnictwo w sferze publicznej, a także dostęp do rynku dóbr oraz usług konsumpcyjnych.

Zdecydowanie zatem dominują aspekty materialne, związane z zagwarantowaniem odpowiednich środków do życia i korzystania z dóbr materialnych. Nie brak jednak zagadnień, które rozwijają sferę ducha, jak dostęp do dóbr kultury, możliwość edukacji, czy wreszcie regulowanie stosunków rodzinnych. Dodatkowo ważna jest ochrona, którą zapewnia prawo karne czy wreszcie możliwość uczestnictwa w życiu publicznym. Ustawodawca za pomocą norm prawnych stara się zabezpieczyć prawa podmiotowe osób starszych, chronić je przed konsekwencjami naruszeń, stawia sobie za cel stworzenie narzędzi prawnych, które byłyby gwarancją w realizacji życiowych celów osób starszych.

\section{OBSZAR ODDZIAŁYWANIA NORM MORALNYCH}

Relacje międzypokoleniowe wyznaczają zakres oddziaływania norm moralnych poprzez postawy społeczne przyjmowane przez uczestników życia społecznego. Chodzi więc o wszelkie oddziaływania międzyosobowe, u podstaw których stoi moralna świadomość człowieka oraz prezentowany przez niego system wartości.

Zauważyć należy, że czynników wpływających na moralność czy też na etyczną postawę osoby jest wiele. Człowiek nie jest czystą kartką, jak chciał Locke, i inni empiryści, na której życie zapisuje wartości. Zakładamy, że człowiek z pewnym podstawowym systemem wartości, z naturalną skłonnością do dobra się rodzi. Nie mniej jednak w odkryciu i ukształtowaniu się tej skłonności, czyli moralności uczestniczy szereg czynników 
[Hohol i Kwiatek 2015]. To są czynniki naturalne i kulturowe, takie jak klimat, stosunki społeczne, czynniki biologiczne, historyczne, demograficzne, ekonomiczne i gospodarcze, wykształcenie i wychowanie oraz świadomość społeczna. Do czynników tych należy zaliczyć również prawo. Tym tłumaczyć można nie tylko w różny sposób definiowaną pozycję osób starszych, ale także stosunek do niej w poszczególnych obszarach geograficznych, kulturowych czy historycznych.

Ten wpływ ma charakter indywidualny, czyli bezpośredni, dotyczący osobistej postawy konkretnego człowieka, jak i też ogólny, dotyczący kształtowania się ogólnych wzorców zachowań, jakie tworzą się w wymiarze społecznym. Inaczej więc do starości podchodzono w starożytności, inaczej czyni się to współcześnie. Inaczej zachowa się w stosunku do starości człowiek, który wychowywał się w wielopokoleniowej rodzinie mieszkającej razem, inaczej ktoś, kto dziadków zna z rodzinnych zdjęć i wspomnień. Czynniki te uaktywniają postawę moralną człowieka, która przejawiać się będzie bądź w afirmacji osób starszych bądź w tendencji do ich wykluczenia. Ta jednostkowa, czy nawet powszechna postawa, obiektywnie nie wpływa na to, co dobre lub złe, nie jest więc relatywna, to znaczy że istnieje fundamentalna zbieżność między ludźmi różnych ras, kultur i wieku w potencjalnym rozumieniu tego, co dobre, a co złe. A zatem w istocie rzeczy na obiektywne istnienie norm moralnych stojących na straży godności osób starszych nie wpływa to, w jakim zakresie i w jaki sposób wyrażana jest postawa moralna. Godność człowieka jest czymś wrodzonym, powszechnym i niezbywalnym i nie zależy od ludzkiej uznaniowości. Zmienia się co najwyżej sposób i zakres jej rozumienia oraz ochrony. Żadne zatem czynniki, w tym prawo, nie mają wpływu na esencjalną treść norm moralnych, mogą jednak warunkować ich rozumienie i zastosowanie. Na potrzeby naszych rozważań posługiwać się więc będziemy pojęciem normy moralnej, którą rozumie się tutaj jako imperatyw o charakterze etyczno-moralnym, stanowiący wzorzec zachowania dla osób i ich grup, wyrażający się w przyjmowanych postawach, zgodny z wyznawanym systemem wartości.

\section{PRAWO A NORMA MORALNA}

Prawo stanowione opiera się na założeniach moralnych, ma bowiem służyć dobru człowieka, w wymiarze indywidualnym i społecznym. 
Kształtuje ono, porządkuje, utrwala i koryguje relacje społeczne, ale ich nie zastępuje. I tak można zauważyć istnienie wielu wymiarów relacji międzypokoleniowej, co do których ustawodawca się nie miesza. Prawo państwowe łączy się $\mathrm{z}$ ingerencją suwerennej władzy w stosunki panujące między podmiotami $\mathrm{w}$ zakresie ich praw i obowiązków. $\mathrm{Z}$ natury nie ingeruje ono w sprawy sumienia, ogranicza się do tego, co istotne, co wynika z konieczności i zasadności uporządkowania relacji. Porządki te cechuje określona autonomia, która jednak zakłada między nimi szereg powiązań.

\section{OBIEKTYWNOŚĆ MORALNOŚCI}

Pierwsza uwaga, jaką należy poczynić wynika z faktu, że prawo stanowione, które jest wyrazem woli prawodawcy, choć może zrodzić powinność moralną, samo jednak w sobie zasad moralnych nie tworzy. Prawo do ochrony zdrowia nie jest wynalazkiem państwa, które co najwyżej powinno starać się zapewnić skuteczną jego ochronę. Moralność rozumiana jako obiektywny i niezmienny porządek, wynikający z prawa Bożego, naturalnego bądź pozytywnego, choć może być zakresowo zbieżna z prawem stanowionym, nie daje ustawodawcy władzy arbitra w decydowaniu o tym, czy coś jest dobre bądź złe, a jego działalność prawodawcza nie może ani bezpośrednio ani nawet pośrednio wpłynąć ani na istnienie zasad moralnych, ani na ich treść. Dotyczy to również zakresu norm. Zadaniem prawodawcy na przykład nie jest decydowanie, komu prawo do ochrony życia i zdrowia należy się bardziej, a komu mniej. Należy jednak zapytać, czy prawo może wpłynąć na moralne przekonania, na jednostkową świadomość dobra lub zła. Tu wpływ wydawałby się oczywisty, a w każdym razie możliwy. Prawo państwowe poprzez swoją sankcyjność, jest najlepszym nauczycielem i przekazicielem norm, i o ile są one zbieżne z normami moralnymi, zostają one przekazane i utrwalone w takim zakresie, w jakim zdefiniowane zostały przez ustawodawcę. I tak prawo do życia gwarantowane jest poprzez normy z prawa karnego ustanawiające sankcję za jego naruszenie. Rezygnacja $\mathrm{z}$ sankcji wpływa najpierw na poczucie bezkarności, stwarza przyzwolenie do działania, ostatecznie przyczyniając się do erozji treści samej normy. To samo dotyczy tak istnienia, jak i zakresu przedmiotowego normy. 


\section{SUBIEKTYWNE ROZUMIENIE MORALNOŚCI}

Moralność pochodzi od łac. słowa moralis - moralny. Według Harta, moralność to społecznie zobiektywizowane, niezinstytucjonalizowane reguły i zasady postępowania oraz standardy ocenne, których treść zrelatywizowana jest do pojęć „dobra”, „słuszności”, „sprawiedliwości”. Jest pewnym zbiorem ocen i norm, wyznawanych faktycznie przez jakąś grupę ludzi. W tym sensie to także moralność będzie oddziaływała na prawo, bo z zasady powinno ono kierować się dobrem, przynajmniej w pewien sposób ujętym, słusznością i sprawiedliwością [Korycka-Zirk 2010, 81]. Jest to pojęcie pojemne, uzależniające swą treść od konkretnie istniejącej sytuacji.

Przez moralność można zatem rozumieć określone postępowanie ludzkie, podlegające ocenie moralnej zrelatywizowanej do pojęć dobra, słuszności lub sprawiedliwości. Postępowanie człowieka jest kwalifikowane przez normy i oceny moralne jako dobre lub złe, słuszne lub niesłuszne. Na tę moralność będzie wpływać prawo, kształtując postawy i zachowania ludzkie. Trzeba jednak stanowczo podkreślić, mimo przyjęcia wyżej cytowanej definicji, że samo pojęcie dobra nie jest względne, nie może być relatywizowane, gdyż ma charakter obiektywny. Żadne prawo stanowione, ludzki zwyczaj czy przekonania tudzież praktyka nie mogą wpływać na treść zasad moralnych, które są niezmienne. Jeśli jednak moralność zredukujemy do tego, jak rozumiane jest dobro lub zło w danej społeczności, czyli sprowadzimy do systemu norm, którymi de facto kieruje się dana grupa społeczna, to takie pojęcie może podlegać działaniu różnych czynników, w tym także prawa stanowionego.

\section{ZŁOŻONOŚĆ RELACJI MIĘDZY PRAWEM A MORALNOŚCIĄ}

Oddziaływanie prawa na moralność może mieć charakter pozytywny, negatywny bądź neutralny. Prawo może nadać treść wykonawczą pewnym moralnym zasadom, może wejść z nimi w konflikt, albo wkraczać na obszar moralnie obojętny. Czasem prawo rości sobie pretensje by wkraczać tam, gdzie normy moralne regulują pewien porządek. Prawo wzmacnia egzekwowalność niektórych norm moralnych i w wielu przypadkach to czyni lub czynić powinno. Na przykład norma nie zabijaj implikuje szereg norm prawnych, które chronią życie na gruncie systemu prawa, gwarantując 
ochronę przedmiotowi, który tego wymaga. Jeśli jednak prawo relatywizuje obowiązywalność tej normy, dopuszczając pod pewnymi względami zabójstwo, to wchodzi w konflikt $\mathrm{z}$ moralnością. Tak się dzieje w przypadku eutanazji, aborcji, czy w pewnych warunkach kary śmierci.

Przechodząc na grunt systemowej ochrony praw osób starszych należy zauważyć, iż o ile słusznym jest założenie, że osoba w podeszłym wieku ma prawo do godziwego zabezpieczenia swoich potrzeb materialnych, co wynika z zasady sprawiedliwości, to polityka emerytalna państwa, w wyniku której z jednej strony przyznaje się pewnym grupom emerytów czy rencistów niskie stawki uposażeniowe, z drugiej ogranicza się im możliwość pracy dodatkowej, obarcza przychody wysokimi podatkami, zmusza do ponoszenia wysokich kosztów leczenia, mogą prowadzić do konfliktu między porządkiem moralnym a prawem stanowionym. Wiąże się to bowiem z utrwalaniem się procesu wykluczenia osób starszych, których prawa do uczestnictwa w życiu społecznym wymagają szczególnych zabezpieczeń. $\mathrm{Z}$ kolei dla przykładu prosenioralne przepisy gwarantujące osobom starszym dostęp do systemu kredytowego pozytywnie wpływają z jednej strony na ich aktualną pozycję materialną, $\mathrm{z}$ drugiej na relacje społeczne w rodzinie i społeczeństwie. Wspólnie zatem z systemem norm moralnych, normy prawne pełnią funkcję regulującą, zbieżną, pomagając $\mathrm{w}$ ochronie wartości moralnych, ale też poprzez wadliwe rozwiązania skazują na bolesne ich konsekwencje.

\section{ZMIENNOŚĆ TREŚCI PRAWA I ROZUMIENIA MORALNOŚCI}

Kolejna uwaga dotyczy faktu, że zarówno prawo pozytywne, jak i zachowania moralne wielu ludzi ulegają ciągłym zmianom we współczesnych społeczeństwach. Ich treść i zmienność jest niezależna, gdyż porządki te nie zawierają się w sobie. Ich treści są jednak ze sobą skorelowane i często na siebie oddziałują. Dotyczy to sytuacji, gdzie np. ustawodawca działając demokratycznie, tworzy normę pokrywającą się treściowo z normą moralną uznawaną przez część obywateli. W ten sposób prawo niejako petryfikuje pewien sposób rozumienia zasad moralnych, sankcjonując ich powszechną obowiązywalność. Wytwarza się pewien schemat, który powoduje, że prawo, które posiada autorytet społeczny, oddziałując na świadomość 
osoby zaczyna wypierać normę moralną dotąd obowiązującą, zastępując ją treścią zawartą w ustawie.

Niektóre normy prawa nie muszą wprost odnosić się do norm moralnych i mogą mieć charakter etycznie obojętny. Ustawa wprowadzająca podwyższony wiek emerytalny jest decyzją opartą na społecznym konsensusie, moralnie obojętną, uznaniową. Jej związek z wymiarem etycznym i ocena moralna może być jednak pośrednia. Może ona bowiem skutecznie ograniczyć możliwość cieszenia się owocami pracy osobom, które statystycznie nie dożywają wieku emerytalnego, lub też pozbawić emerytów dostępu do godziwego życia, stwarzając im niedogodne warunki ekonomiczne do godziwego spędzenia starości. Prawo stojące $\mathrm{w}$ sprzeczności z zasadami moralnymi utrwala schematy wykluczenia, prowokując sytuacje poniżenia coraz bardziej uznawane za normę społeczną, w której społeczeństwo nie potrafi zadbać i uszanować osób w podeszłym wieku.

\section{OBSZAR WSPÓLNEGO ODDZIAŁYWANIA}

Badania socjologiczne i historia ukazują oddziaływanie prawa na moralność. Prawo wpływa na postawy moralne i świadomość moralną społeczeństwa. Klasycznym tego przykładem było prawne usankcjonowanie i towarzyszące mu przy tym przyzwolenie społeczne względem niewolnictwa. Istniejące luki w przepisach podatkowych, umożliwiające wielomilionowe wzbogacenie się na niekorzyść państwa sprawiają, że ci którzy dzięki nim zdobywają fortuny, nazywani są ludźmi przedsiębiorczymi, podczas gdy według obiektywnych norm moralnych powinni zostać nazwani złodziejami. Prawo kształtuje i modyfikuje zastane oceny moralne. Wytwarza się bowiem w społeczeństwie pewien konsensus, coś co uważane było za obojętne moralnie, lub wręcz złe, zaczyna być uznawane za możliwe, dopuszczalne, czy wręcz za dobre. I odwrotnie. Taki mechanizm widoczny był $\mathrm{w}$ systemach totalitarnych, gdzie prawo dopuszczało stosowanie przemocy w stosunku do jednostek słabszych, doprowadzając wręcz do ich unicestwienia. W społeczeństwie o chrześcijańskich korzeniach w III Rzeszy, gdzie zdecydowana większość mieszkańców znała i wyznawała chrześcijańskie zasady moralne, na skutek praw nazistowskich rozpowszechniło się ogólne przyzwolenie na eksterminację ludzi chorych, starych i z uwagi na rasę uznanych za gorszych. Prawo wpływa zatem w sposób istotny na 
uznawanie i przestrzeganie norm moralnych, zaś moralne przekonania ludzi ukształtowanych w kulturze euroatlantyckiej są rezultatem wielowiekowego religijnego i kulturowego rozwoju społeczeństw. Ten rozwój dokonywał się między innymi poprzez akty prawa.

\section{KRYZYS MORALNY W PODEJŚCIU DO STAROŚCI}

Rozwój gerontologii oraz wzrost liczebny osób starszych wzmacnia ich pozycję i skłania do działań polepszających ich status. Ogólnie jednak dominuje przekonanie o trudnym położeniu osób starszych. Sąd taki opiera się na czynnikach ekonomicznych, jak i na ogólnym prestiżu, jakim cieszą się poszczególne grupy wiekowe, mające wpływ na życie społeczne kraju. Prestiżu takiego z zasady pozbawieni są ludzie w podeszłym wieku. Ludzie starsi są marginalizowani, często lekceważeni na wielu obszarach życia publicznego i społecznego. Wiąże się to $\mathrm{z}$ problemem wykluczeń społecznych.

Mimo, iż w społeczeństwie, w którym głęboko zakorzeniona jest godność osoby i jej praw, nie obce jest zjawisko dyskryminacji ze względu na wiek. Typowym i powszechnym zjawiskiem jest tzw. ageizm, polegający na tym, że osoby w codziennych sytuacjach spotykają się z przykrymi dla nich stereotypami związanymi z ich wiekiem. Dotyczy to urzędów, ośrodków opieki zdrowia, w miejscach aktywności zawodowej czy w środkach komunikacji i przekazu. Ich niesprawność zamiast budzić chęć pomocy, często wzbudza ostracyzm, niechęć, w najlepszym przypadku litość. Nie raz mają one poczucie, że nikomu nie zależy na inwestowaniu w nie, tak gdy chodzi o edukację, jak i opiekę zdrowotną. Znane są przypadki odmowy lub zaniechania leczenia ze względu na wiek. Ich potencjalność zawodowa, kompetencja, doświadczenie przestają być źródłem zainteresowania ludzi młodych [Zrałek 2007, 101]. Takie stereotypy często doprowadzają do postaw dyskryminujących, do uprzedzeń, gorszego traktowania [Wieczorek 2005, 195].

Fakt, że w wielu codziennych sytuacjach ludzie starsi są gorzej traktowani, mają utrudniony dostęp do ważnych dóbr i usług - w istotny sposób ogranicza ich szanse i możliwości rozwoju, decyduje o jakości ich życia. Często czują się niedowartościowani, a obiektywnie rzecz biorąc, społeczeństwo traci solidne zaplecze i potencjał możliwy do budowania wspólnego dobra. 
Taki stan rzeczy wynika w głównej mierze z braku skutecznych regulacji prawnych, które wzmocniłyby ich pozycję, lepiej chroniły ich prawa ekonomiczne, socjalne, dawały lepszy dostęp do ochrony zdrowia, pozwalały szerzej uczestniczyć w życiu edukacyjnym, kulturowym, lepiej zagospodarowały niemały potencjał, jakim dysponują ludzie starsi.

Ludzie starsi często nie mają siły i narzędzi, by skutecznie dochodzić swych praw. Główne problemy polegają na tym, że starszym kobietom i mężczyznom często odmawia się dostępu do usług (np. bankowych), miejsc pracy lub pozbawia szacunku z uwagi na ich wiek oraz inne czynniki, takie jak płeć lub niepełnosprawność. Ludzie starsi poddawani są często przemocy, w tym przemocy słownej, psychologicznej i finansowej nie tylko w placówkach opiekuńczych, ale także w środowisku domowym. I tak wskazuje się, że z uwagi na swój wiek osoby starsze mogą nie otrzymywać odpowiedniej opieki zdrowotnej lub społecznej, wskazuje się na brak systemowej opieki geriatrycznej, nieuwzględnianie w kontraktowaniu usług medycznych odmienności i wyższych kosztów leczenia osób starszych. Sygnalizowane są przypadki lekceważenia dolegliwości starszych pacjentów i postrzegania ich przez lekarzy jako nieuniknione objawy starzenia się, nawet jeśli można je leczyć. Także w dostępie do niektórych programów profilaktycznych stosowane są ograniczenia wiekowe.

Bolesnym problemem jest brak zabezpieczenia finansowego $\mathrm{w}$ postaci emerytury i innych form zabezpieczenia społecznego, co w wielu przypadkach skutkuje ubóstwem.

Osoby starsze uznawane są za „niezdolne” do pracy ze względu na swój wiek, a nie kwalifikacje. Starsi pracownicy są mniej chętnie wysyłani na szkolenia lub zmuszani do zaprzestania pracy ze względu na osiągnięty wiek emerytalny.

Kolejnym problemem są wciąż powszechne bariery architektoniczne i urbanistyczne, które ograniczają możliwości poruszania się. Chodzi tu o niefunkcjonalny rozkład pomieszczeń w mieszkaniach, brak wind, podjazdów, zbyt wysokie krawężniki, schody zewnętrzne pozbawione zjazdów i poręczy, a także nierówne i pełne dziur chodniki [Wieczorek 2005, 195].

Podane wyżej przykłady mogą dać obraz na pewien stan świadomości społecznej, w której wartość osoby podeszłej wiekiem nie jest zauważana, doceniana i chroniona. U podstaw tego typu zjawisk i sytuacji stoi brak odpowiednich regulacji prawnych. W konsekwencji osoby starsze nie korzystają z zabezpieczeń $\mathrm{i}$ dostępu do ochrony zdrowia, narażone są na 
powszechnie obecną przemoc, $\mathrm{w}$ tym przemoc $\mathrm{w}$ rodzinie, nie korzystają z systemów prewencji, itd.

Poprzez brak stosownych regulacji, prawo nie spełnia swojej funkcji ochronnej i wychowawczej. Osoby starsze, żeby zachować swój status społeczny, muszą mieć możliwości korzystania z dóbr materialnych, a ich prawa powinny być lepiej chronione, gdyż im samym trudniej jest ze zrozumiałych powodów praw tych dochodzić i z nich korzystać. Starość, która często jest naznaczona zmęczeniem i wyniszczeniem powinna być nagrodą za godziwe pracowite życie. Brak odpowiedniej ochrony prawnej jeszcze bardziej pogłębia proces wykluczenia.

\section{DE LEGE FERENDA}

Trudna sytuacja osób starszych domaga się odpowiednich działań legislacyjnych. Tam, gdzie ich sytuacja jest zła, zwłaszcza na płaszczyźnie ochrony życia i zdrowia, konieczne są odpowiednie i stanowcze regulacje oraz dyscyplina w ich egzekwowaniu. To właśnie prawo ma do dyspozycji sankcje dyscyplinujące, których nie mają w wystarczającym i skutecznym stopniu inne systemy aksjologiczne.

Fakt, że normy moralne pozbawione są sankcji wpływa na ich ograniczoną skuteczność. Niezachowanie wartości moralnej nie skutkuje już dzisiaj większą uciążliwością. Ewentualny wyrzut sumienia, spowodowany wyrządzoną krzywdą staremu ojcu lub matce, niegdyś stanowiący skuteczny bodziec korygujący, łatwo złagodzić konsumpcjonistycznym i nihilistycznym stosunkiem do życia, i wesprzeć zasadą tolerancji i pluralizmu światopoglądowego. Można więc powiedzieć, że ani moralność ani religia nie są tak skutecznym egzekutorem treści normy moralnej, jak jej zgodność z normą prawną.

Jest oczywiste, że w przypadku ochrony osób starszych, to prawo powinno wspierać wartość i treść normy moralnej, egzekwując jej zachowanie oraz wprowadzając skuteczny mechanizm, który z czasem wytworzy nawyk jego zachowania oraz zrozumienie i wewnętrzną akceptację dla chronionej wartości, jaką stanowi dobro osób starszych [Dziedziczak 2015, 86].

Wydaje się że w związku z tym, wobec zaprezentowanych wyżej sytuacji patologicznych, które skutkują różnego rodzaju formami dyskryminacji osób starszych, konieczne jest, by prawo w większym stopniu 
ingerowało i regulowało panujące stosunki, zdecydowanie eliminując istniejące patologie. Prawo nie powinno zastępować ani wyręczać moralności, ingerować w zwyczaje. Ich wzajemna autonomia powinna być zachowana, nie mniej jednak w społeczeństwie, w którym dochodzi do kryzysu wartości, zgodnie z zasadą pomocniczości, obowiązkiem państwa powinno być roztropne włączenie się w kształtowanie odpowiednich stosunków społecznych w takim zakresie, w jakim jest to pożyteczne i konieczne [Lorek 2016, 145].

W Polsce problem dyskryminacji i marginalizacji osób starszych zauważany jest stosunkowo od niedawna, a w związku ze zmianami społecznymi ostatnich dziesięcioleci znacznie się nasilił. Być może spowodowane to jest przemianami gospodarczymi i społecznymi, a może bardziej erozją systemu wartości. Zdania specjalistów na temat przyczyn ageizmu są podzielone. Jedni upatrują dyskryminacji i wykluczenia społecznego w sferze finansowej, inni jej źródła dostrzegają w sferze społecznej i edukacyjnej [Szukalski 2016, 245]. Bezsprzecznym jest jednak fakt, ze zarówno z przyczyn etycznych, jak i ekonomicznych osoby starsze stanowią grupę niewidoczną dla społeczeństwa, a tym samym izolowaną społecznie, dyskryminowaną i marginalizowaną.

W czasach, gdy nie było systemów emerytalnych ani innych zabezpieczeń socjalnych, jedyną gwarancją na starość było potomstwo, które w odpowiednim momencie zajmowało się starymi rodzicami. Dziś może warto byłoby w kształtowaniu systemu opieki i ochrony osób starszych postawić na politykę prorodzinną oraz wspieranie tej odpowiedzialności, która zawsze spoczywała na naturalnych więzach rodzinnych [Lorek 2018, 130]. Przyczyniłoby się to do skuteczniejszej, tańszej i bardziej humanistycznej opieki z zachowaniem wszelkich praw i norm etycznych, jakie stoją na straży dobra i porządku.

$\mathrm{Z}$ drugiej strony konieczne jest, by ustawodawca dostrzegł także z własnego punktu widzenia, potencjał ludzki, społeczny i ekonomiczny, jaki drzemie w ludziach starszych, starając się tak kształtować politykę społeczną, by dobrze wykorzystać i zintegrować dobra wszystkich. Obecność osób starszych odpowiednio włączonych w sieć społecznych powiązań, może tylko przyczynić się do większych korzyści oraz wypełnić wymogi społeczeństwa opartego na prawie i wartościach wyrażających się w moralno-społecznych postawach ludzi. 


\section{PIŚMIENNICTWO}

Balcerzak-Paradowska, Bożena. 2007. „Rodzina i polityka rodzinna wobec osób starszych.” W W obliczu starości, red. Lucyna Frąckiewicz, 121-30. Katowice: Ośrodek Wydawniczy Augustyna w Katowicach.

Baron-Wiaterek, Małgorzata. 2007. „Administracja publiczna wobec osób w podeszłym wieku.” W W obliczu starości, red. Lucyna Frąckiewicz, 105-20. Katowice: Ośrodek Wydawniczy Augustyna w Katowicach.

Bois, Jean P. 1996. Historia starości. Od Montaigne’a do pierwszych emerytur. Warszawa: Wydawnictwo Marabut.

Cudowska, Agata, red. 2011. Kierunki rozwoju edukacji w zmieniającej się przestrzeni społecznej. Białystok: Wydawnictwo Trans Humana.

Dziedziczak, Wojciech. 2015. „Wpływ sankcji prawnych i moralnych na skuteczność prawa." Studia Iuridica Lublinensia XXIV, nr 1:67-86.

Fabiś, Artur, red. 2007. Instytucjonalne wsparcie seniorów - rozwiązania polskie i zagraniczne. Bielsko-Biała: Wyższa Szkoła Administracji w Bielsku-Białej.

Frąckiewicz, Lucyna. 2007. „Starość jako problem społeczno-ekonomiczny.” W W obliczu starości, red. Lucyna Frąckiewicz, 17-38. Katowice: Ośrodek Wydawniczy Augustyna w Katowicach.

Halicka, Małgorzata. 1995. „Historyczna zmienność traktowania starości.” Gerontologia Polska 3-4:42-44.

Kijak, Remigiusz, i Zofia Szarota. 2013. Starość. Między diagnozą a działaniem. Warszawa: Centrum Rozwoju Zasobów Ludzkich.

Kłobukowska, Justyna. 2016. „Pozycja i ochrona seniorów na rynku bankowości detalicznej w perspektywie zrównoważonych finansów.” Finanse i Prawo Finansowe 3, nr 1:71-82.

Korycka-Zirk, Milena. 2010. „Reguły prawne jako istota pojęcia prawa w ujęciu H.L.A Harta." Studia Iuridica Toruniensi 6:81-100.

Longchamps de Berier, Franciszek. 2008. „Autonomia prawa i moralności.” Zeszyty Społecznej Myśli Kościoła. Chrześcijaństwo - Świat - Polityka 1:25-31.

Lorek, Kamil. 2018. „Prawne aspekty związane z ochroną seniorów w społeczeństwie polskim.” Annales Universitatis Mariae Curie Sklodowska LXV, 2:129-45.

Łączkowski, Wojciech. 2000. „Prawo i moralność.” Poznańskie Studia Teologiczne 9, 205-11.

Maj, Elżbieta. 2012. „Sytuacja społeczna oraz prawna ochrona osób starszych.” Ruch Prawniczy, Ekonomiczny i Socjologiczny LXXIV, nr 3:189-201.

Pikuła, Norbert. 2014. „Senior w centrum oddziaływań edukacyjnych.” Przegląd Pedagogiczny 2:130-39.

Rembowski, Józef. 1984. Psychologiczne problemy starzenia się człowieka. Poznań: Państwowe Wydawnictwo Naukowe.

Rudnik, Anna. 2016. „Wymiary starości i cechy ludzi starych w percepcji dzieci i młodzieży." Pogranicze. Studia Społeczne 28:201-19.

Szarota, Zofia. 2004. Gerontologia społeczna i oświatowa: zarys problematyki. Kraków: Wydawnictwo Naukowe Akademii Pedagogicznej.

Szatur-Jaworska, Barbara, red. 2008. „Stan przestrzegania praw osób starszych w Polsce.” Biuletyn Rzecznika Praw Obywatelskich nr 65 (Materiały).

Szukalski, Piotr. 2012. „Przyczyny ageizmu. Fakty i mity.” W Zagrożone człowieczeństwo. T. 2: Obszary zagrożeń człowieka $w$ realiach współczesności, red. Ewa Kantowicz, i Grażyna Orzechowska, 245-60. Kraków: Impuls. 
Urbaniak, Bogusława. 2016. „Polityka państwa wobec osób starszych na rynku pracy.” Problemy Polityki Społecznej 3:72-88.

Wawrzyniak, Joanna. 2007. „Funkcjonowanie stereotypu starości w społeczeństwie.” Gerontologia Społeczna 1 (2).

Zimmermann, Jan. 2013. Aksjomaty prawa administracyjnego. Warszawa: Wolters Kluwer Polska.

\author{
Uwagi co do prawnej ochrony osób starszych \\ i jej wpływu na kształtowanie się postaw moralno-społecznych
}

Streszczenie

Ochrona osób starszych wynika $\mathrm{z}$ ich kondycji biologicznej generującej szeroką gamę ograniczeń. Godność osoby ludzkiej oraz oparty na niej szereg praw podmiotowych domaga się wprowadzenia prawnych zabezpieczeń. Powinny one nie tylko zagwarantować ludziom starszym dostęp do dóbr i usług, ale też pozytywnie wpłynąć na rozumienie moralnych zobowiązań względem nich, czyli na kształtowanie się moralno-społecznych postaw. Właściwie skonstruowane prawo jest nośnikiem treści zawartej w normach moralnych. Za jego pośrednictwem utrwalane zostają prosenioralne zachowania. Ma to szczególne znaczenie nie tylko z tytułu sprawiedliwości, jaka należy się ludziom starszym, ale przyczynia się do właściwego zagospodarowania potencjału, jakim pod względem materialnym, duchowym i społecznym dysponują ludzie starsi.

Słowa kluczowe: godność człowieka; prawa podmiotowe osób starszych; starość; gerontologia

Comments on the Legal Protection of Older People and its Impact on the Formation of Moral and Social Attitudes

\title{
Summary
}

The protection of older people is the consequence of their biological condition which is related with a wide range of restrictions. The dignity of the human person and a number of subjective rights require legal safeguards. These legal norms should not only guarantee the older people access to goods and services, but also have a positive influence on understanding of moral obligations towards them. That is on the shaping of moral and social attitudes. The law is to be a carrier of moral norms. It is to organize a social order. This is particularly important not only for the justice which should relate to older people but also to others.

Key words: human dignity; subjective rights; old age; gerontology

Information about Author: Rev. JAROSŁAW KRZEWICKI, PH.D. - Pontifical University of St. Thomas Aquinas; Largo Angelicum 1, 00184 Roma RM, Italy; e-mail: krzew@ libero.it; https://orcid.org/0000-0002-9595-9497 